\title{
Research Paper \\ Producton and marketing dynamics of major vegetables in Bharuch district of South Gujarat
}

\author{
P. M. Thanki, Deepa B. Hiremath, Alok Shrivastava and R. D. Dhandhukia
}

Correspondence to :

Alok Shrivastava Department of Agricultural Statistics, College of Agriculture, (N.A.U.) Bharuch (Gujarat) India

Email : igkvalok@nau.in

Paper History :

Received : 12.08.2017;

Revised : 04.02.2018

Accepted : 17.02.2018
ABSTRACT : Gujarat has a vast contribution to the Indian horticulture sector. It contributes nearly five per cent of the total vegetable production in India. The state also enjoys leading position at allIndia level in the productivity levels of major vegetables like onion, potato, tomato, brinjal etc. Bharuch district is situated on the Bank of Narmada river, the lifeline of Gujarat and is well known for its well developed Industrial areas. Arabian Sea braces its west side. The geology of the district with vast area affected by inherent/coastal salinity, presents a complex hydrogeological pattern, consequently leading to vast variation in the quality and quantity of vegetables produced. The return from vegetable cultivation is also volatile due to its highly perishable nature and instable prices. Thus, due to dearth of literature about the economics of production, marketing and associated constraints for Gujarat state, a study was conducted to work out the cost of cultivation and returns per hectare, the marketing cost per quintal, marketing efficiency as well as to identify the constraints related to cultivation and marketing of selected vegetables viz., brinjal, green tur, bottle gourd, okra, pointed gourd. Some of the results which emerged from the study were that the total marketing cost incurred per quintal by the vegetable growers was the lowest in case of in green tur crop (Rs. 70.50) while highest in case of bottle gourd (Rs. 98.00). On an average, the total marketing cost per quintal incurred was Rs. 80.25/qtl of which major share was accounted by transportation cost i.e. Rs. 54.25/qtl (67.60 \%) followed by packing cost $(26.79 \%)$ and loading-unloading $(5.61 \%)$. The net return per hectare was found to be positive in all vegetable crops. The net return/hectare over cost $C_{2}$ was highest (Rs. 449041.00) in case of pointed gourd and lowest in bottle gourd (Rs. 172236.00). The input -output ratio over $\mathrm{Cost}_{2} \mathrm{C}_{2}$ was the lowest in case of green tur (1:1.49) and highest in pointed gourd (1:2.24).

KeY WordS : Marketing costs, Margins, Cost of cultivation, Marketing efficiency, Price spread

How To Cite This PAper : Thanki, P.M., Hiremath, Deepa B., Shrivastava, Alok and Dhandhukia, R.D. (2018). Producton and marketing dynamics of major vegetables in Bharuch district of South Gujarat. Internat. Res. J. Agric. Eco. \& Stat., 9 (1) : 184-193, DOI : 10.15740/HAS/IRJAES/9.1/184-193. 